\title{
The age and origin of eastern Australian diamonds: Re-Os isotope evidence from sulfide inclusions in two diamonds from Wellington, New South Wales.
}

\author{
Pearson, D.G. ${ }^{1}$, Davies, R.M. ${ }^{2}$, Shirey, S.B. ${ }^{3}$, Carlson, R.W. ${ }^{3}$, Griffin, W.L. ${ }^{2}$, \\ 1. Department of Geological Sciences, Durham University, South Rd, Durham, DH1 3LE, U.K. \\ 2. GEMOC National Key Centre, School of Earth Sciences, Macquarie University, Sydney, NSW, 2109. \\ Australia. \\ 3. Department of Terrestrial Magnetism, Carnegie Institution of Washington, 5241 Broad Branch Rd, N.W. \\ Washington, DC 20015, U.S.A.
}

\section{Introduction/regional geology}

Occurrences of alluvial diamonds along the dominantly Phanerozoic margin of eastern Australia have been well documented. Most attention has been devoted to diamonds from the Copeton and Bingara deposits, which appear to be highly unusual in terms of their inclusion compositions and carbon isotopic signatures (Sobolev, 1984). However, many diamonds at other locations, e.g., Wellington, New South Wales, show features much more in common with kimberlite-derived diamonds occurring on cratons (Davies et al, this volume).The origin and age of the eastern Australian diamonds is a controversial topic with significant bearing on the genesis of diamonds in non-cratonic regions (e.g., Sobolev, 1984; O’Reilly, 1989; Baron et al, 1996; Griffin et al, 1998). Because of the unusual setting of the diamonds there are few geological factors that may be used to constrain their age. The aim of this study has been to try to date some of the diamonds and also constrain their provenance using the Re-Os isotope system on single sulfide inclusions. The regional geology in the areas where alluvial diamonds occur in eastern Australia is considered to be dominantly Phanerozoic. Basement consists of early- to mid-Paleozoic orogenic complexes of the Lachlan Fold Belt together with parts of the Mesozoic New England Fold Belt but some tectonic models invoke delamination of more ancient lithospheric mantle (Turner et al 1996). Handler et al (1997) have recently provided convincing evidence of early Proterozoic mantle from Mt. Gambier, beneath the edge of the Gawler craton, much further SW than the diamonds discussed here. The aim of this study was to constrain the age of diamond growth in this region, and to constrain better the nature of their source regions.

\section{Samples \& diamond population}

Diamonds The Wellington diamonds occur in the Macquarie River system, cutting the Lachlan Fold Belt. Davies et al (this vol.) have divided the Wellington diamonds into 2 main groups, termed A and B. Group A are largely of peridotitic paragenesis, with inclusions of olivine, wustite and pentlandite and this group makes up $80 \%$ of the diamond population at Wellington. The sulfides studied here are from this group. These diamonds have normal $\mathrm{C}$-isotopic signatures and internal growth structures typical of kimberlite/lamproite-derived diamonds (Davies et al, this vol.). Furthermore, etch features comparable to those observed on the surfaces of diamonds from kimberlites and lamproites occur on Group A diamonds. Group B diamonds are similar to those from Copeton and Bingara, and have more eclogitic affinities, although numerous samples have 
anomalously heavy C-isotopic compositions (Sobolev, 1984). The abundance ratio of Group A to B diamonds is 4:1 at Wellington, in contrast to the predominance of Group B stones at Copeton and Bingara (Davies et al, this vol.). Surface features of Group B diamonds suggest that they have experienced a different alluvial history to Group A.

Nitrogen contents and aggregation: The two diamonds studied, W92 and W119 are morphologically similar, with very resorbed glossy surfaces. W119 has a core region with $500 \mathrm{ppm} N$ of which $60 \%$ is aggregated to the $\mathrm{IaB}$ form, and comes from a sub-group with generally high $\mathrm{N}$ contents, relatively low $\mathrm{N}$ aggregation states and octahedral growth zoning. There is a sharp rim transition on W119 to diamond with lower $\mathrm{N}(60 \mathrm{ppm})$ and lower aggregation $(17 \% \mathrm{IaB})$. W92 has $450 \mathrm{ppm} \mathrm{N}(10 \%$ or less $\mathrm{IaB}$ ). This diamond comes from a rare sub-group of unusual stones with low $\mathrm{N}$ contents (140$900 \mathrm{ppm}$ ) but high $\mathrm{N}$ aggregation (45 to $95 \% \mathrm{IaB}$ ). Internal growth structures in this group are complex and show multiple growth and resorption events. High degrees of plastic deformation are observed in group B that may have enhanced nitrogen aggregation (Davies et al, this vol.). The different $\mathrm{N}$ contents and $\mathrm{N}$-aggregation characteristics of W119 and W92 combined with their differing surface and morphological features indicate they may not be from the same diamond population. Sulfide inclusions : Two pentlandite sulfide inclusions from separate diamonds were analysed for Re-Os isotopes using a new micro-chemistry technique (Pearson et al, in press). Re concentrations were determined with an Elan 6000 ICP-MS and CeTac direct injection nebuliser. The sulfide inclusion in $\mathrm{W} 119$ contains $22.2 \% \mathrm{Ni}$ and that in W92 contains $17 \% \mathrm{Ni}$. W92 is surrounded by a relatively silica-rich $\left(10.0\right.$ to $\left.19.9 \% \mathrm{SiO}_{2}\right)$, high $\mathrm{NiO}(37.6$ to $52.1 \% \mathrm{NiO})$ reaction rim of uncertain origin.

\section{Re-Os isotope results}

Sulfide Os contents are 20.7 to $14.7 \mathrm{ppm}$, within the range previously reported from pentlandites in other diamonds (Bulanova et al, 1996; Pearson et al, in press and submitted). The two sulfide inclusions have very different Os isotope ratios (Table 1), but both are significantly less radiogenic than bulk Earth ( $\gamma \mathrm{Os}_{\mathrm{i}}-4.8$ to -13.4$)$.

\section{Table 1. Os isotope data for Wellington sulfide inclusions in diamonds.}

\begin{tabular}{llllll}
\hline Sample & Re ppb & Os ppb & $\mathbf{1 8 7 0 \mathbf { S } / 1 8 8 0 \mathbf { s }}$ & $\gamma \mathbf{O s}_{\mathbf{i}}$ & $\mathbf{T}_{\mathbf{m a}} \mathbf{G a}$ \\
W92 & 490 & 20664 & $0.11002 \pm 17$ & -13.4 & $3.4 \pm 0.3$ \\
W119 & 706 & 14687 & $0.12088 \pm 57$ & -4.8 & $2.1 \pm 0.3$ \\
\hline
\end{tabular}

The least radiogenic value is significantly lower than the lowest value recorded from peridotite xenoliths from S.E. Australia by Handler et al (1997); Fig. 1. Interestingly, this low value is well within the range observed for cratonic peridotites (Fig.1) and overlaps the range of Os isotope compositions measured in Siberian P-type diamonds so far. $\mathrm{C}$-isotope compositions, internal growth structure and morphology indicate that Group A diamonds may be kimberlite/lamproite derived, probably from a cratonic area. The Re depletion ages (minimum likely age of Os for the two sulfides are 0.93 and $2.5 \mathrm{Ga}$. Re-Os model ages date the crystallisation of the diamond if the inclusion is syngenetic. W92 thus appears to have formed in the Archaean, in agreement with Os results from Siberian P-type diamonds. This formation age is consistent with the notion of a 
conventional source for Group A diamonds, being derived from a craton to the West through alluvial reworking (Davies et al, this vol.). The more radiogenic Os isotope composition of W119 is well within the range of S.E. Australian lithospheric peridotites (Fig. 1) but its Re-Os model age suggests formation in the Proterozoic. This age contrasts with W92, but is consistent with the idea that the two diamonds may come from separate populations.

Fig. 1 . Initial Os isotope composition of $2 \mathrm{E}$. Australian diamonds compared to Kaapvaal peridotite xenoliths (Pearson et al, 1995) and S.E. Australian peridotite xenoliths (Handler et al, 1997).

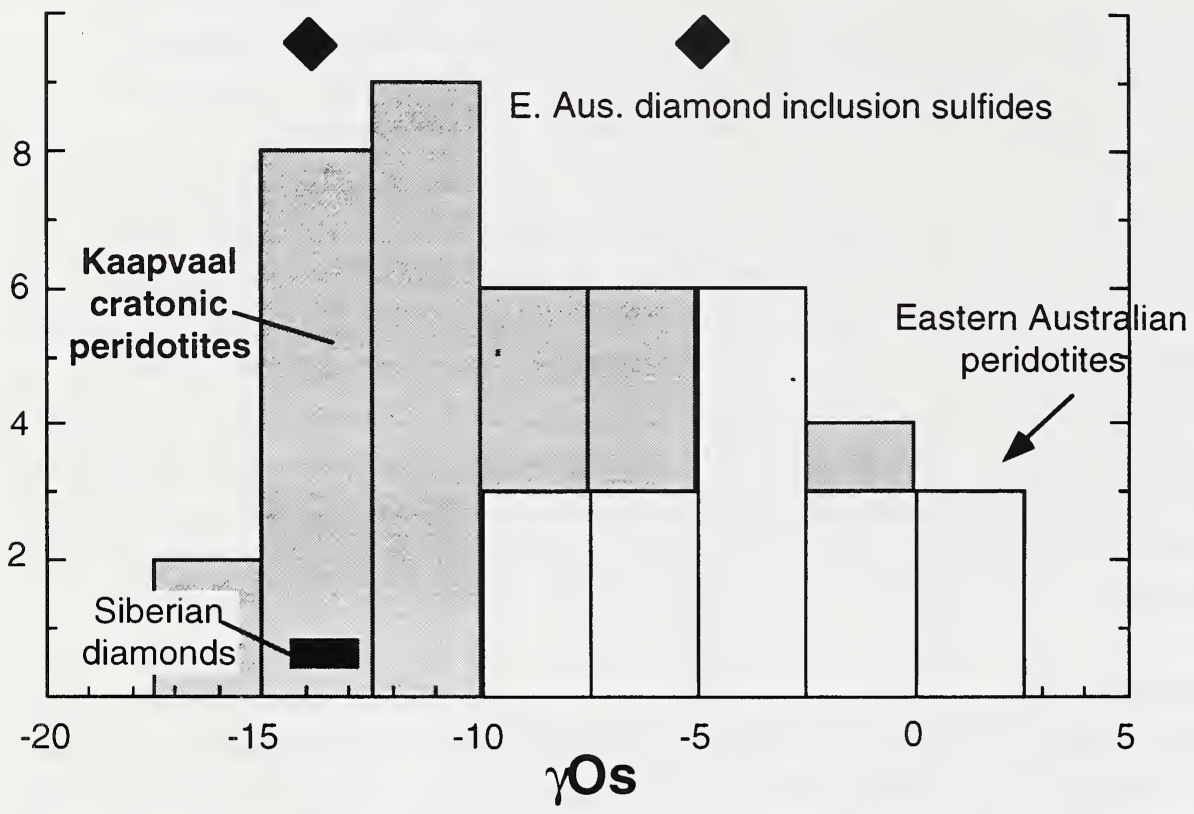

\section{References}

Bulanova, G.P.. Griffin, W.L., Ryan, C.G., Shestakova, O.Ye, and Barnes, S-J., 1996, Trace elements in sulfide inclusions from Yakutian diamonds: Contrib. Mineral. Petrol. 124, p111-125.

Davies, R.M., O'Reilly, S.Y. and Griffin. W.L., 1997. Characteristics of alluvial diamonds from Bingara and Wellington, eastern Australia: This volume.

Griffin, W.L., O’Reilly, S.Y. \& Davies, R.M., 1998, Subduction-related diamond deposits?: Constraints, possibilities and new data from Eastern Australia: Rev. in Econ. Geol.

M.R. Handler, V.C. Bennet \& T.M. Esat, 1997, The persistence of off-cratonic lithospheric mantle: Os isotopic systematics of variably metasomatised southeast Australian xenoliths: Earth Planet. Sci. Lett., 151, p.61- 75.

O'Reilly, S. 1989, Nature of the east-Australian lithosphere: in Johnson, R. W. (ed.) Intraplate volcanism in eastern Australia and New Zealand. Cambridge University Press, p 290-297.

Pearson, D.G., Carlson, R.W., Shirey, S.B., Boyd, F.R., Nixon, P.H., 1995, The stabilisation of Archaean lithospheric mantle: A re-Os isotope study of peridotite xenoliths from the Kaapvaal craton: Earth Planet. Sci. Lett.134, p.341-357.

Pearson, D.G., Shirey, S.B., Harris, J.W., \& Carlson, R.W., in press, Constraining diamond crystallisation ages: A Re-Os isotopic study of sulfide diamond inclusions from the Koffiefontein kimberlite, S. Africa: Earth Planet. Sci. Lett. Pearson, D.G., Shirey, S.B., Bulanova, G.P., \& Carlson, R.W. and Milledge, H.J., submitted, Single crystal Re- Os isotope study of sulfide inclusions from a Siberian diamond: Geochim. Cosmochim. Acta.

Sobolev, N.V., 1984, Crystalline inclusions in diamonds from New South Wales, Audtralia; in Glover, J.E. and Harris, P.G. (eds.), Kimberlite Occurrence and Origin- a basis for Conceptual Models in Exploration, Univ. Western Australia, Pub. 8, p213-226. 